INTERNATIONAL DESIGN CONFERENCE - DESIGN 2018

https://doi.org/10.21278/idc.2018.0347

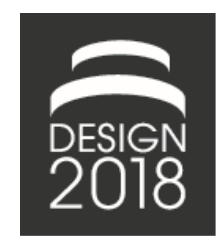

\title{
DESIGNING A LIFE SITUATION TOOL IN CO-CREATIVITY: PROPOSAL FOR A TOOL ADAPTED TO FABLABS
}

\author{
J. Lobbé, F. Bazzaro and J.-C. Sagot
}

\begin{abstract}
Today, in user-centred design, the user is integrated alongside the design team. In our work, we propose to go further and to integrate the user in the phases of co-creativity. Indeed, the user could be considered an expert of his life situation, so that his participation in all phases of the product design process is also essential. We propose to explore the very specific world of FabLabs. In particular, we will ask how to enable design experts and Makers to work around the life situation. We propose to apply user-centred methodologies to design a life situation tool in co-creativity.
\end{abstract}

Keywords: design process, design creativity, co-design, life situation, fablabs

\section{Introduction}

Today, in user-centred product design methodologies, the user is integrated alongside the design team (Bazzaro et al., 2012; Nelson et al., 2013). These methodologies aim to integrate the user in all his functional, social and emotional dimensions (Barcenilla and Bastien, 2009; Arhippainen, 2013) to the design project through the intervention of experts in human factors such as ergonomists or product designers. These user-centred design methodologies are based on taking into account the user, his environment, and the interaction between the product and the user (ISO, 2010). These different components and their inter-relations can be defined under the notion of life situation.

We describe the life situation as "the result of determining and tangible elements, such as the characteristics of the user, the environment and the product, and of intangible elements, such as the user's emotions and perceptions. This combination creates an experience" (Lobbé et al., 2017). The tangible elements correspond to the elements accessed during the analysis by experts from the user, the environment, and the product. The intangible elements correspond to the elements defined by the user experience which is defines by the "perception and reaction of a person resulting from an effective and/or anticipated use of a product, system or service" (ISO, 2010). These elements are only accessible by the user. This concept of life situation clearly underlines the central role of the user and the need for his involvement in the product design process. Indeed, the user could be considered as an expert in his own life situation, therefore his participation in all phases of the product design process is also essential. We consider the user as an everyday expert (Sennett, 2009).

In many works in the various currents of user-centred design, the user is already largely integrated into the analysis and evaluation phases of the future product (Keates and Clarkson, 2003; ISO, 2010; Herst, 2012; Stappers et al., 2012); in our work we propose to go further and also integrate the user in the phases of creativity situated after the analysis step (ISO, 2010), and more specifically to the co-creativity phases. Indeed, co-creativity can be defined as "creativity that is shared by two or more people" (Sanders 
and Stappers, 2008). This is an integral part of co-design which "refers to co-creation used in the course of the design process" (Stappers et al., 2012).

Many authors have been interested in these notions of co-creativity or co-design between technical and user experts (Aoussat et al., 2000; Visser et al., 2005; Sanders and Stappers, 2008; Bazzaro et al., 2012; Charrier et al., 2014). As far as we are concerned, we have decided to position ourselves in the very specific world of FabLabs where the user is a central player in the steps of co-creativity, situated very early on in the design process; and where this co-creativity could be done between users and not necessarily with design experts. We talk about Makers (Anderson, 2012). They are "Do-It-yourselfers" who consider product design from the hobby point of view, the practice and sharing of skills (Bosqué, 2015). FabLabs (Fabrication Laboratory) (Gershenfeld, 2008) are open places for innovation, manufacturing, creation and knowledge sharing. In these places, the design processes are mainly based on a dynamic of co-creativity and the active participation of the end-user. In this article, we will ask how to enable a team of design experts and Makers to work around the concept of life situation. We will ask ourselves, which method and tools to put in place in the specific context of co-creativity with the Makers. With this purpose, we propose to apply the methodologies of user-centred design to design our life situation tool from the context of FabLabs. To achieve this, we set up a co-creativity session in a Maker universe during the Fablab Festival, which over four days brings together the FabLabs, Makers, researchers, companies and the general public of Europe and the World. During this session of cocreativity, we propose to co-build with the Makers this life situation tool. For this, during the session, we analyze the traces produced by the participants to study the criteria of the life situation essential to our tool. We present this approach in the rest of this article.

\section{State of the art}

\subsection{From user-centred design to FabLabs}

The aim of user-centred design is to develop new products that are both desirable and acceptable. With this purpose, it's necessary to include the end-user into the design process (Keates and Clarkson, 2003; ISO, 2010). User-centred design is a multidisciplinary movement: technical experts, human factor experts and end-users are all involved in the design process. The design team thus constituted guarantees the user's expectations and needs (Ulrich and Eppinger, 1999; Sagot et al., 2003).

Many authors from engineering, ergonomics and industrial design (Quarante, 1994; Pahl and Beitz, 1996; Ulrich and Eppinger, 1999; Sagot et al., 2003) have proposed several models to integrate at least one of the actors of the design team. The design models from user-centred design (ISO, 2010) or universal design (Keates and Clarkson, 2003) allow the integration of all the experts actors of the design team and of the user. We presented in Figure 1 a simplified model of user-centred design.

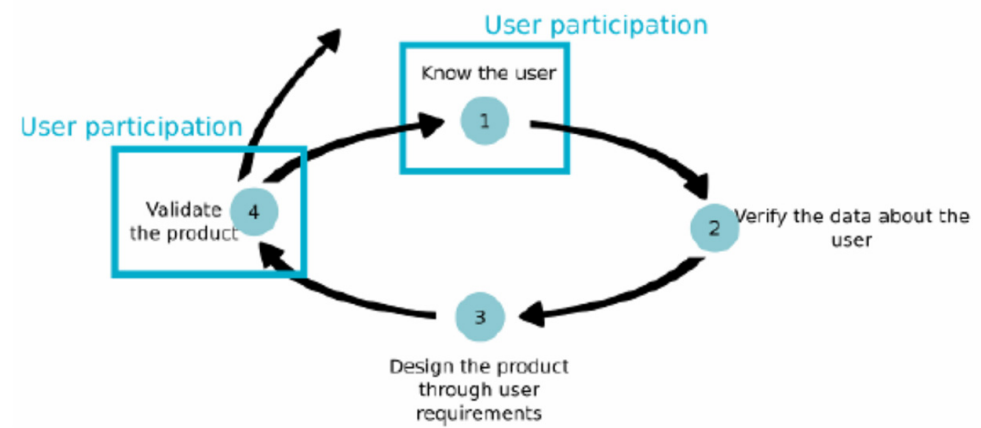

Figure 1. User-centred design process (Keates and Clarkson, 2003; ISO, 2010)

According to the model presented above, the user-centred design process is an iterative loop in four steps. Step 1, "know the user", is a user analysis phase carried out by a team of experts in human factors, with the help of the participation of the end-user as the object of study (Bisgaard and Høgenhaven, 2010). Step 2 , "verify the data about the user", is a phase of formalization of the data collected during the first step. This step makes it possible to formulate the user needs more clearly. Step 3, "design the product", is a 
design step. During this phase, the design team proposes solutions and concepts that respond to the needs formulated during step 2. Step 4, "validate the product", is a validation step of the concept, prototype or product using the participation of the end-user as tester (Bisgaard and Høgenhaven, 2010).

The analysis and validation steps already integrate the user through the participation of the human factor experts, so we are particularly interested in our research about the integration of the life situation and the user as an actor in step 3, "design the product". Indeed, the user is a specialist in his life situation (Visser et al., 2005; Sanders and Stappers, 2014). Therefore, he could bring an expertise to the project, by his knowledge and understanding of his life situation. In addition, he could be integrated into this creative phase of the user-centred design process, where some solutions are proposed to respond to the needs already collected. This approach is consistent with the proposal of Bisgaard and Hogenhaven (Bisgaard and Høgenhaven, 2010), which defines four typologies of user-centred innovation: "User test", "User exploration", "User Innovation" and "User participation". In the context of our work, we are clearly positioned in the "User Innovation" and "User participation" context.

This dimension of the integration of the user makes it possible to have access to the user's acknowledged and unacknowledged needs (Bisgaard and Høgenhaven, 2010).

This evolution of the user role in the design process is particularly observable in open co-creation workshops, such as FabLabs. These very open spaces of innovation, manufacturing, creation and sharing of knowledge thus appear as an approach to integrate the user into the design process. This integration is based on "an individual approach based on the dual" competence of the user, "both technician" and "able to formulate a fairly precise and realistic definition of the needs". We are talking here about an "innovative user" (von Hippel, 2005) and more specifically in FabLabs about a Maker. The Makers are the users of the FabLabs, they consider product design from the hobby point of view and the practice and sharing of skills (Bosqué, 2015). They are primarily pushed into a project by their daily problems as well as by their personal skills (von Hippel, 2005). The world of "Make" is carried by the "Do It Yourself" and "Do It With Others" (Lallement, 2015; Morel and Le Roux, 2016). According to Troxler, this methods involve "moving away from the traditional multidisciplinary and time-consuming approaches [common in engineering], to adopting a fast, interdisciplinary and iterative approach" (Menichinelli et al., 2015a). It's tends to favor creativity and innovation (Lallement, 2015). In the rest of this article, we place ourselves in step 3, "design the product", with a design team comprised of Makers to enrich the user-centred design process. We can therefore talk about co-creativity.

The freedom and the flexibility of a co-creativity session are in accordance with the values of the Makers and the practices in FabLabs (Lallement, 2015). With this perspective, in the rest of this article we are interested in the life situation tools used as a creativity tool.

\subsection{Life situation tool as a creativity tool}

The life situation (Maguire, 2001; Valentin et al., 2010) can be defined as "the result of determining and tangible elements, such as the characteristics of the user, the environment and the product, and of intangible elements, such as the user's emotions and perceptions. This combination creates an experience" (Lobbé et al., 2017). The intangible elements correspond to the elements defined by the user experience (Hassenzahl, 2003; Desmet and Hekkert, 2007) they are only accessible by the user. The tangible elements correspond to the result of the design team analysis. We retain the data concerning the user, the product and the environment as tangible elements of the life situation. According to this definition of life situation, we identify a life situation framework made of five elements to consider during the project: the user, the environment, the product, the activity of the user, and his state during the action. Firstly, user characteristics, physical and temporal environment, and product characteristics are easily accessible by the design team (Lobbé et al., 2017). Secondly, the elements of the user experience (Arhippainen and Tähti, 2003; Hassenzahl, 2003; Barcenilla and Bastien, 2009; ISO, 2010), such as knowledge, perceptions or reactions, are often accessible only by the user.

The life situation is studied during the analysis step of the design process proposed in Figure 1, "know the user". It can also be used all along the different creativity steps. As part of our research, we are particularly interested in the co-creativity phases during the step "design the product" in Figure 1. We can identify two groups of tools that allow us to represent this life situation: storyboarding and mapping tools. Storyboarding and storytelling tools are used to illustrate the interaction between the user and 
his/her product. The story makes it possible to visualize the activity and create empathy (Carroll, 2000; Martin and Hanington, 2012). Mapping tools, such as the user journey map, are used to represent graphically the interactions between the user and his product. They allows us to discuss the life situation and improve it (Martin and Hanington, 2012; Patton, 2014). These two tools are based on the experience lived by the user interacting with his product in his environment. In Table 1, we compare the two tools according to our life situation framework (Lobbé et al., 2017).

Table 1. Comparison of the main life situation tools with the life situation framework

\begin{tabular}{|c|c|c|c|}
\hline \multicolumn{2}{|c|}{ Criterion } & $\begin{array}{c}\text { Is the criterion represented } \\
\text { with the storyboard? }\end{array}$ & $\begin{array}{c}\text { Is the criterion represented } \\
\text { with the mapping tool? }\end{array}$ \\
\hline \multirow[t]{4}{*}{ The user } & Physical characteristics & yes & yes \\
\hline & Cognitive abilities & no & no \\
\hline & Social environment & yes & yes \\
\hline & Personality and values & no & no \\
\hline \multirow{2}{*}{$\begin{array}{l}\text { The Physical } \\
\text { environment }\end{array}$} & Place & yes & no \\
\hline & Ambience & no & no \\
\hline $\begin{array}{l}\text { The Temporal } \\
\text { environment }\end{array}$ & Schedule, duration & yes & yes \\
\hline \multirow[t]{2}{*}{ The product } & Functionality & yes & no \\
\hline & Aesthetic and sensory & no & no \\
\hline \multirow[t]{2}{*}{ The activity } & Motivation & yes & yes \\
\hline & Action & yes & yes \\
\hline \multirow{3}{*}{$\begin{array}{l}\text { The state of the } \\
\text { user }\end{array}$} & Physical and sensory & yes & yes \\
\hline & Cognitive & no & no \\
\hline & $\begin{array}{l}\text { Sentimental, emotional } \\
\text { and hedonism }\end{array}$ & yes & yes \\
\hline
\end{tabular}

According to an analysis of the literature (Carroll, 2000; Truong et al., 2006; Atasoy and Martens, 2011; Martin and Hanington, 2012), the two tools have the same level of detail to describe the user. On the other hand, they are not equally used to describe the cognitive abilities and the personality and values of the user. The environment is better represented with the storyboard, where the place is represented. Meanwhile, the product is only represented by its functionality with the storyboarding. The activity and the state of the user have the same level of details with both tools. So, the storyboarding and mapping tools alone are not sufficient to describe the life situation. Thus, we seek to design a new design tool to take into account the totality of the life situation defined in the framework. addition, the sharing of knowledge can often be difficult in multi-skilled teams (Sagot et al., 2003; Barré et al., 2017). These tools are typically used by human factor experts such as ergonomists and product designers. In the case of the Makers, these specific tools are not always transparent. Indeed, these tools specific to the design are not necessarily intelligible by everyone, each one having its own culture and language and employing "words similar to the meanings [often] different according to the trades and [the] disciplines" (Bassereau et al., 2016). To put all the project actors on an equal footing, we are interested in a concept that appears to us to be broader: traces. Indeed, traces can be defined as what is said, done, written, drawn, modeled, etc. (Derrida, 2014). Traces are thus tools usable by all the participants of a cocreativity session contrary to intermediaries' objects. They are defined as communication media representing the future product between the different project-actors. These have already been used in conventional design processes (Vinck et al., 1996). In the rest of the article, we are looking to put in place a tool for design experts inspired by the world of Makers. This tool will make it possible to work around the life situation in the context of co-creativity during the step "design the product" in Figure 1. With this goal, we proposed to understand the context of use for our future tool through the case of the Makers and the FabLabs, to put in place a tool adapted to this specific case. 


\subsection{Analysis of the context of use for our life situation tool}

We propose to analyse the context of use for our life situation tool, more precisely to define the user of the future tool and his environment. With this goal, we carried out an analysis with a literature review regarding one of our future users - the Maker - and our environment - the FabLab and the co-creativity session. We propose an analysis data collection of the user of our co-creativity tool: the Maker who is the least experienced user in the methods and design tools; and its environment of use: the co-creativity session in FabLabs. We performed this data collection through the knowledge framework proposed by Charrier (2016) to combine all the data of our analysis. Firstly, we presented the analysis of the Maker in Table 2.

Table 2. The analysis of the Maker

\begin{tabular}{|c|c|c|}
\hline \multicolumn{2}{|c|}{ The Maker } & \multirow{6}{*}{$\begin{array}{c}\text { References } \\
\text { (Bottolier-Depois et } \\
\text { al., 2014; Makery, } \\
\text { 2014, 2017; } \\
\text { Lallement, 2015; } \\
\text { Menichinelli et al., } \\
\text { 2015b; Morel and Le } \\
\text { Roux, 2016) }\end{array}$} \\
\hline Sociodemographic characteristic & $\begin{array}{c}\text { Hackers / Makers } \\
78 \% \text { men } 22 \% \text { women } \\
65 \% \text { general public } \\
\text { startups, children, researchers, artists, } \\
\text { artisans, employees, etc. }\end{array}$ & \\
\hline $\begin{array}{c}\text { Psychological and cognitive } \\
\text { characteristics }\end{array}$ & $\begin{array}{c}\text { Bac }+4 / 5 \\
\text { skills and knowledge } \\
\text { TIC, Design studies }\end{array}$ & \\
\hline Personality & $\begin{array}{l}\text { liberty } \\
\text { meet other people, sharing } \\
\text { curious, good mood }\end{array}$ & \\
\hline Social and cultural characteristics & learn, make, share & \\
\hline Ideological characteristics & $\begin{array}{l}\text { help projects that make sense } \\
\text { help to find solutions to concrete } \\
\text { problems }\end{array}$ & \\
\hline
\end{tabular}

Secondly, we presented the analysis of a co-creativity session in the context of the FabLabs in Table 3. This analysis is a combination of the element of the FabLabs environment and the co-creativity session environment.

Table 3. The analysis of the co-creativity session in a FabLab

\begin{tabular}{|c|c|c|}
\hline \multicolumn{2}{|c|}{ The Environment } & \multirow{3}{*}{$\begin{array}{l}\text { References } \\
\text { (Carroll et al., 2009; } \\
\text { Makery, 2014, 2017; } \\
\text { Lallement, 2015; } \\
\text { Menichinelli et al., } \\
\text { 2015b; Morel and Le } \\
\text { Roux, 2016) }\end{array}$} \\
\hline Physical characteristics & $\begin{array}{c}\text { sounds of conversations, machine, music } \\
\text { bazaar and agitation } \\
\text { workshop smells, coffee, food }\end{array}$ & \\
\hline $\begin{array}{l}\text { Social and cultural } \\
\text { characteristics }\end{array}$ & $\begin{array}{c}\text { curious } \\
\text { open to all, user-friendly, freedom, comfort } \\
\text { not failure } \\
\text { wifi, machine, creativity equipment and } \\
\text { prototyping } \\
\text { network, play } \\
\text { learn, make, share }\end{array}$ & \\
\hline Temporal characteristics & $\begin{array}{l}\text { absence of constraint } \\
\text { duration of a co-creativity session: } 1-2 \text { hours }\end{array}$ & \\
\hline
\end{tabular}

After this initial study of the literature, we seek to understand in the rest of this article the current practices in the FabLabs in order to enrich the user-centred design process and to propose a life situation tool adapted to the co-creativity. The tool will be a mix between a storyboard and a user journey map to take into account the totality of the life situation. For this purpose, we propose a co-creativity workshop around the life situation in the context of FabLabs. 


\section{Material and methods}

During the Fablab Festival of May 2017 in Toulouse, we proposed to realize a co-creativity workshop open to all. This festival brings together FabLabs, Makers, researchers, companies and the general public of Europe and the World for four days since 2014. The objective of the workshop was to co-build a life situation mapping during a co-creativity session with design experts and Makers.

\section{Participants}

Our workshop gathered 11 participants. One of these was the facilitator. He is a design expert in mechanical engineering, ergonomics and product design, who knew the project and was there to animate the co-creativity session. The 10 remaining participants, of very different ages from 5 to 55 years, were quite representative of Maker type profiles: children, students, engineers, technicians and educators.

The participants didn't know about the project in advance. So as not to limit the participants' creativity, we did not set a time limit for our workshop. It closes naturally after an hour of creativity when each actor considers that he has expressed his ideas.

The goal is for our participants to complete the mapping of a daily activity "take medication for a senior" with the elements at their disposal.

\section{Material and analysis performed}

To allow the launch of the project, the representation and the communication with the participants, 166 documents which had been reviewed and synthesized by human factor experts, namely an ergonomist and a product designer, were proposed to the participants: one Persona, a stereotypical representation of the end-user; six visual analysis boards of the project; a type of trend chart; and a cultural probe composed of 11 objects representing the user and the life situation "take medication for a senior" (Martin and Hanington, 2012). These objects and documents, allowed the participants to understand the project, and offered a common support for starting the discussion and group work.

The objective of the workshop was to complete a mapping of the life situation. The participants also had at their disposal creativity materials, namely markers, modelling clay, post-it notes, articulated puppets representing the user and some pictograms. Moreover, the participants had some completion elements to represent the life situation, namely one hundred photographs and visuals, and pre-written verbatim associated with each step of the activity. We prefer to favour the number of photographs, as visual traces seem to be easier to access for participants who do not know the project. Indeed, children participate in this workshop and need to use common references that can be used by all.

We proposed some stickers, "life situation criteria", for describing the life situation and the user experience. This list of criteria was developed to describe and evaluate the life situation during the design process (Arhippainen and Tähti, 2003; Kremer and Lindemann, 2015). This list was developed so that the concepts used would be understandable by all the participants in the workshop, who are not experts in human factors. We grouped the life situation criteria under generic and more accessible terms for non-experts. Furthermore, the facilitator was able to detail the criteria at any time. We thus retained the physical and sensory reaction (pain, sensation, etc.), the emotions (pleasure, joy, sadness, etc.), the mood (concentration, stress, agitation, calm, cognitive reaction, etc.), the autonomy (complexity of the task, accessibility, freedom, etc.), the social relations (solitude, need for a companion, etc.), the effort to be provided, the comfort, the motivation and the achievement of the objective. We present all the material available for the workshop in Figure 2.

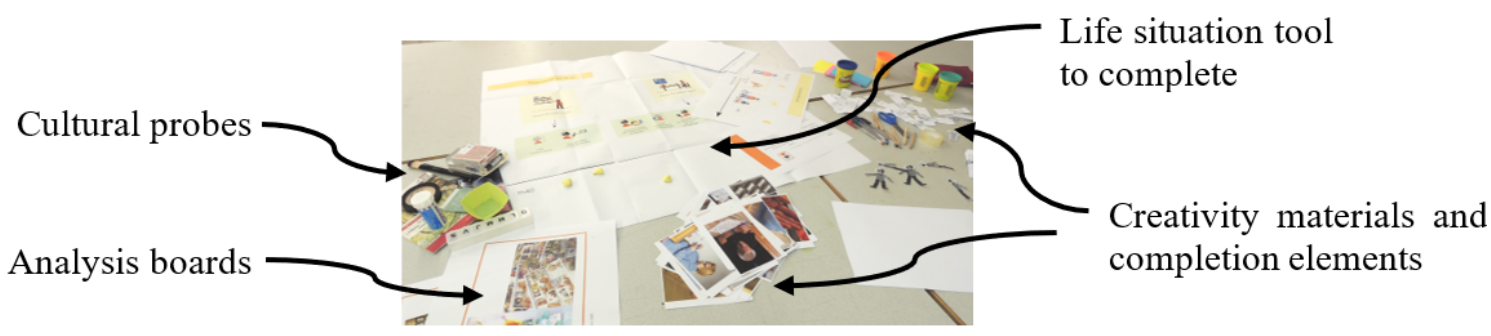

Figure 2. Preparation of the workshop 
We carried out a first qualitative analysis of the traces proposed to the participants at the beginning of the workshop, and a second of the traces used by the participants at the end of the workshop. To complete the mapping, we made available to participants different traces, namely texts, photographs, artefacts and pictograms. The traces used by the participants to complete the mapping were photographs, artefacts, pictograms, drawings, writings and modelling. After one hour, we made a detailed count of these traces as previously specified.

\section{Results}

We present in Figure 3 the dedicated workspace and the mapping done at the end of the workshop after one hour.

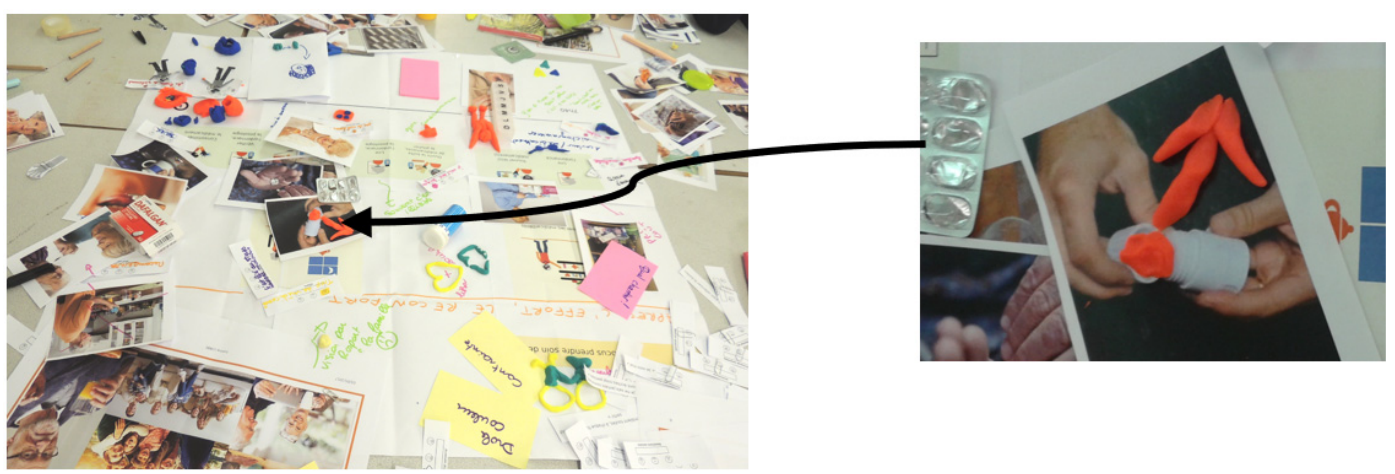

Figure 3. Result of the workshop and example of modelling on photography

We performed a counting of the different traces present on the cartography at the beginning and the end of the workshop: the words, the visuals, the modelling and the physical artefacts. The Figure 4 shows the evolution of the different typologies of traces (texts, photographs, artefacts, pictograms, drawings, writings, modelling) during the co-creativity workshop.

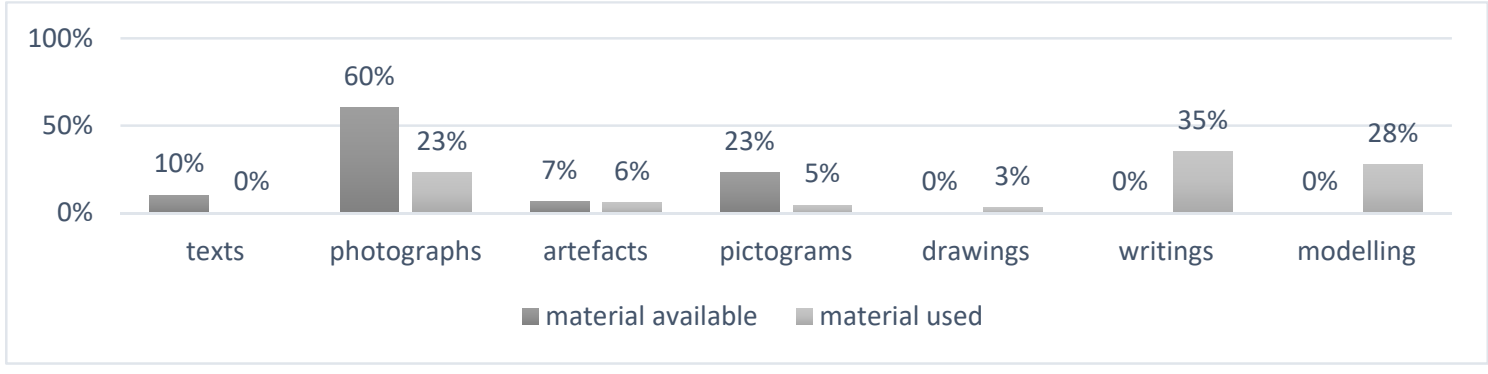

Figure 4. Evolution of traces during the one-hour co-creativity workshop

At the beginning of the workshop, all the traces proposed were divided into four formats, namely $10 \%$ texts written by machine, $60 \%$ photographs, $7 \%$ physical artefacts from the cultural probe and finally $23 \%$ pictograms. At the end, six formats were used, including four of those initially proposed: photographs, artefacts, pictograms, drawings, writings, modelling. One format remained unused by the participants: the texts. The traces used were divided as follows: $23 \%$ photographs, $6 \%$ artefacts, $5 \%$ pictograms, $3 \%$ drawings, $35 \%$ manual writings and finally $28 \%$ modelling.

The pre-written verbatims were not present on the map; participants preferred to use their own words with $35 \%$ handwriting. Pictograms and other simplified visuals were used at $5 \%$. We found a small percentage of drawings and sketches at 3\%. On the other hand, the percentage of use of the artefacts remained unchanged. The participants in the workshop used the products to make a concrete idea or gesture explicit about a tangible tool. We also found that users did not hesitate to use their own products, which they knew and used regularly. A participant, to illustrate his words, used his own tube of medication. Representations in modeling clay were also used at $28 \%$ to represent products, postures or movements. 
We also noted the association or combination of some traces. For example, modelling was sometimes associated with photographs or products. A participant thus mixed the two types of photography and modeling traces to explain a gesture, as presented in Figure 3. Concerning the criteria of the life situation, $60 \%$ of the 10 elements present at the end of the workshop were in relation to the state and the emotional reactions of the user. The remaining $40 \%$ were equally divided between the user's state or physical reactions and the user's motivation. The notion of social environment was also regularly used to describe the different visuals used. On the other hand, the other elements characteristic of a user experience, notions of mood, autonomy, effort or comfort, were not used by the participants. Motivation, although well represented in the red thread on the cartography, was not accompanied by the notion of objective. Finally, we also found during our workshop that the criteria of the life situation were used to re-start the reflections in the manner of a card game by drawing a criterion at random and completing the mapping according to the criterion indicated.

\section{Discussion and conclusion}

A state-of-the-art analysis of user-centred design and the FabLabs allowed us to position these places in the design process. That allowed us to understand the evolution towards a participative dimension of product design practices. This evolution has led us to move closer to the Makers' universe based on "Do It Yourself" and "Do It with Others" (Lallement, 2015; Morel and Le Roux, 2016), in order to better understand and to learn from their practices. Indeed, the Makers are invested in the projects by their skills and as experts on their life situation (von Hippel, 2005).

The integration of the Maker into the design process is rewarding for the understanding of the life situation. To this end, we asked ourselves about the tools used to define the life situation. By comparing them to the definition of the life situation, we realized that the tools of the storyboard and the user journey maps do not take into account all the elements of the life situation. Indeed, these two tools do not allow us to work about the cognitive abilities and reactions of the user, his personality and values, the physical ambience of the environment and the aesthetic and sensory aspect of the product.

In this article, we sought to co-build this life situation tool with the Maker. This tool aimed to enable a team of design expert and Makers to work around the complete concept of the life situation. With this aim, we proposed to understand the current practices in the FabLabs to enrich the user-centred design process. For this purpose, we organized a co-creativity workshop around the life situation in the context of FabLabs.

To this end, we proposed a workshop open to all in which participants were invited to complete a mapping of the life situation using tools adapted to co-creativity (Sanders et al., 2010; Beuthel and Wohlauf, 2017). In order to work on the concept of life situation, our tool combines and completes the tools used in user-centred design: user journey maps and storyboards. Our tool was associated with a needs analysis conducted by experts in human factors. The analysis was synthesized through a persona, analysis boards and a cultural probe.

Through the co-creativity workshop, we sought to understand which tools and which traces allowed the user to participate in the design process. To this end, we brought traces that were easily understandable by non-experts of the design. Our analysis was therefore mainly composed of photographs. For this we compared at the beginning and the end of the workshop, the traces usable by the participants and the traces used by them to complete the mapping.

Our study highlights the type of traces most used by the participants among those we proposed and the themes that were favoured by the participants of the workshop. Concerning the traces, the participants mainly used the elements of their daily life and the tangible elements that they had at their disposal, such as the photographs, the products or the onomatopoeias. The tools kit, the cartographies and the cultural probes, and the traces, visual or modelling, put at the disposal of our participants contribute greatly to the highlighting of this type of traces (Sanders et al., 2010). These authors propose a framework for participatory design with tools and technique grouped into three categories "making tangible things", "talking, telling and exploring" and "acting, enacting and playing", which agrees with our study. Our analysis on the quantification of the traces shows the elements used by the participants to complete the cartography. The user-centred design tools are then needed by the makers to complete our tool. Our futur tool have to take into account these three categories. The use of visual 
and tangible traces (Magnusson et al., 2017) allows participants to express themselves fully and easily about the life situation. According to these authors, the tangible artefacts are particularly important to involve "users who are unfamiliar with the technology". Indeed, in our study, the users expressed themselves spontaneously through non-standardized tools. In the Maker universe, where design processes are informal, our tool allowed us to collect a set of traces that could be used in the long term to enrich the classical methodology of product design. In terms of themes, participants expressed themselves in their own words to talk about emotions and the social environment associated with the experience and life situation. They preferred to spontaneously use onomatopoeia understandable by all. This spontaneity is particularly remarkable in co-creativity workshops involving children (Roussel and Fleck, 2015). Some authors highlight the richness of a co-creativity session with children (Roussel and Fleck, 2015) and with the Makers (Hyysalo et al., 2014) by their motivations and abilities to propose solutions.

Throughout the workshop, we observed through the participants' behaviors the importance of the play dimension in our workshop. The importance of the game is already recognized in participatory design (Sanders et al., 2010) and through the implementation of numerous games to promote innovation (Hohmann, 2006; Gray et al., 2010). In our study, participants were eager to play during the session. Our workshop represented for them a free and uncertain activity but with its own rules proposed by the facilitator. These elements were part of the criteria defining the game (Triclot, 2011). This finding is supported by informal interviews conducted throughout the festival with actors from the disability community and FabLab.

This experience of co-construction of co-creativity gives us guidelines to iterate our tool. Indeed, like a game we must have several elements. Firstly, the free character of the foundation tool of the Maker philosophy: this freedom is found in the temporal environment associated with the workshop but also in the appropriation of traces by users. Secondly, the settled nature of the workshop. These rules must be present through the facilitator of the workshop and through the tools available to handle. A facilitator is needed to explain the "rules of the game", relaunch discussions, and give leads without influencing participants. This guiding role is also provided by the tools proposed in the manner of cards in a game. This notion of a map brings us closer to other methods used in design, such as card sorting (Martin and Hanington, 2012) or UX cards (Lucero, 2009; Lallemand, 2015). On the other hand, these tools do not consider the life situation as a whole. Moreover, they are not always accompanied by methodologies that allow them to be implemented in co-creativity workshops.

This study allows us to propose a brief for our tool. This brief is in accordance with user-centred design methodologies and aims to integrate the tool into this process. It aims to allow a team of designers accompanied by users to work together around the concept of the life situation. We present it below in Table 4.

This brief will lead us to a co-construction in co-creativity of our future tool. Our tool can therefore be composed of tangible objects representing some elements of the life situation. We will thus be able to propose to the users of the tool three cubes respectively representing the characteristics of people, places and time. Then we will try to bring to our future tool a playful dimension. For that we propose axes to work on the theme of the tool and the methodology associated to this tool. We will propose a tool based on the theme of theatre in line with the philosophy of the storyboarding and our definition of the life situation (Lobbé et al., 2017). In this way, our tool is in agreement with the rule of the three units action, time, place - around one person or more, defined by Boileau (1674) in the French classical theatre. And to complete the elements related to the reaction of people during the action, the user of the tool will have at his disposal a dice representing the different criteria that compose the life situation, like emotions, social relations and sensory, cognitive and physical reactions.

This co-built approach of our tool will allow us to go to the end of the participatory design process. Indeed, it is original as a result of the idea that a tool must be built and reflected according to the same design process put in place for a product. User involvement provides access to their unmet needs (Brown, 2009), increasing the innovative potential of a product. It then seems natural to draw a parallel with the tools used by the design teams, all experts combined, namely ergonomist, product designer and engineer. In the rest of our research, we will try to test our tool through a project carried out in an industrial context with users to validate it. 
Table 4. Design brief of the life situation tool

\begin{tabular}{|c|c|c|}
\hline The tool must ... & Requirements & Criterion \\
\hline \multirow[t]{8}{*}{... be participative } & \multirow[t]{3}{*}{ Be easy to use } & $\begin{array}{c}\text { Be understandable for all - Use } \\
\text { physical artefacts and visual traces }\end{array}$ \\
\hline & & $\begin{array}{c}\text { Be usable by all - Use physical } \\
\text { artefacts and visual traces }\end{array}$ \\
\hline & & $\begin{array}{l}\text { Be intuitive, does not need } \\
\text { training - Use physical artefacts } \\
\text { and visual traces }\end{array}$ \\
\hline & \multirow[t]{2}{*}{ Require minor costs } & In terms of materials \\
\hline & & In terms of budget \\
\hline & \multirow{3}{*}{$\begin{array}{c}\text { Be in agreement with the values of } \\
\text { the Makers }\end{array}$} & Be flexible \\
\hline & & Promote freedom \\
\hline & & Be playful \\
\hline \multirow{12}{*}{$\begin{array}{l}\text {... integrate the User-centred } \\
\text { design process }\end{array}$} & \multirow{4}{*}{$\begin{array}{l}\text { Integrate data extracted from the } \\
\text { user analysis }\end{array}$} & About the User \\
\hline & & About the environment \\
\hline & & About the activities \\
\hline & & About the product \\
\hline & \multirow[t]{3}{*}{ Provide usable results } & Concrete results \\
\hline & & Clear and understandable results \\
\hline & & Usable results \\
\hline & \multirow{5}{*}{$\begin{array}{l}\text { Integrate all the elements to } \\
\text { describe life situation }\end{array}$} & About the User \\
\hline & & About the environment \\
\hline & & About the activities \\
\hline & & About the product \\
\hline & & About the state of the user \\
\hline \multirow[t]{3}{*}{... facilitate creativity } & \multirow[t]{3}{*}{ Integrate the creativity rules } & Promote communication \\
\hline & & Focus on a subject \\
\hline & & Stimulate creativity \\
\hline
\end{tabular}

\section{References}

Anderson, C. (2012), Makers: The New Industrial Revolution, Random House.

Aoussat, A., Christofol, H. and Coq, M.L. (2000), "The new product design - a transverse approach", Journal of Engineering Design, Vol. 11 No. 4, pp. 399-417. https://doi.org/10.1080/09544820010000971

Arhippainen, L. (2013), “A Tutorial of Ten User Experience Heuristics”, Proceedings of International Conference on Making Sense of Converging Media, AcademicMindTrek '13. ACM, New York, NY, USA, p. 336. https://doi.org/10.1145/2523429.2523491

Arhippainen, L. and Tähti, M. (2003), "Empirical evaluation of user experience in two adaptive mobile application prototypes", Proceedings of the 2nd International Conference on Mobile and Ubiquitous Multimedia, pp. 2734.

Atasoy, B. and Martens, J.-B. (2011), “Crafting User Experiences by Incorporating Dramaturgical Techniques of Storytelling", Proceedings of the Second Conference on Creativity and Innovation in Design, DESIRE '11, ACM, New York, NY, USA, pp. 91-102. https://doi.org/10.1145/2079216.2079230

Barcenilla, J. and Bastien, J.-M.-C. (2009), "L'acceptabilité des nouvelles technologies: quelles relations avec l'ergonomie, l'utilisabilité et l'expérience utilisateur?", Le Travail Humain, Vol. 72, pp. 311-331. https://doi.org/10.3917/th.724.0311

Barré, J., Buisine, S. and Aoussat, A. (2017), "Persona logical thinking: improving requirements elicitation for multidisciplinary teams", CoDesign, Vol. 13 No. 2, pp. 1-20. https://doi.org/10.1080/15710882.2017.1301959

Bassereau, J.-F., Pello, R.C., Faucheu, J. and Delafosse, D. (2016), "Les objets intermédiaires de conception / design, instruments d'une recherche par le design", Sciences du Design, No. 2, pp. 48-63.

Bazzaro, F., Charrier, M. and Sagot, J.-C. (2012), "Design et ergonomie: facteurs d'innovation dans la conception”, 47ème Congrès International de la Société d'Ergonomie de la Langue Française (SELF). 
Beuthel, M. and Wohlauf, A. (2017), "Participatory Design 101: Co-Creating Tangible User Interfaces to Enrich a Business Trip Experience", Proceedings of the Eleventh International Conference on Tangible, Embedded, and Embodied Interaction, ACM, New York, USA, pp. 781-784. https://doi.org/10.1145/3024969.3025052

Bisgaard, T. and Høgenhaven, C. (2010), Creating new concepts, products and services with user driven innovation, Nordic Council of Ministers.

Bosqué, C. (2015), "Enquête au coeur des Fablabs, hackerspaces, makerspaces. Le dessin comme outil d'observation. Essais de bricologie", Ethnologie de l'art et du design contemporains, No. 64, pp. 168-185.

Bottolier-Depois, F., Dalle, B., Eychenne, F., Jacquelin, A., Kaplan, D. et al. (2014), Etat des lieux et typologie des ateliers de fabrication numérique.

Brown, T. (2009), Change by Design: How Design Thinking Transforms Organizations and Inspires Innovation, Harper Collins.

Carroll, E.A., Latulipe, C., Fung, R. and Terry, M. (2009), “Creativity Factor Evaluation: Towards a Standardized Survey Metric for Creativity Support", Proceedings of the Seventh ACM Conference on Creativity and Cognition, C\&C '09, ACM, New York, NY, USA, pp. 127-136. https://doi.org/10.1145/1640233.1640255

Carroll, J.M. (2000), "Five reasons for scenario-based design", Interacting with Computer, Vol. 13 No. 1, pp. 4360. https://doi.org/10.1016/S0953-5438(00)00023-0

Charrier, M. (2016), Ergonomie et design dans une démarche de conception de produits centrée sur les besoins des personnes, $\mathrm{PhD}$ thesis, Université de Technologie de Belfort-Montbeliard.

Charrier, M., Bazzaro, F. and Sagot, J.-C. (2014), "Ergonomie et design industriel au service de la conception pour tous : étude exploratoire en contexte pédagogique”, 49ème Congrès International de la Société d'Ergonomie de la Langue Française (SELF), pp. 8.

Derrida, J. (2014), Trace et archive, image et art, Suivi de Hommage à Jacques Derrida, par Daniel Bougnoux et Bernard Stiegler, Collège iconique, Ina Editions.

Desmet, P.M.A. and Hekkert, P. (2007), "Framework of Product Experience", International Journal of Design, Vol. 1 No. 1, pp. 13-23.

Gershenfeld, N. (2008), Fab: The Coming Revolution on Your Desktop--from Personal Computers to Personal Fabrication, Basic Books.

Gray, D., Brown, S. and Macanufo, J. (2010), Gamestorming: A Playbook for Innovators, Rulebreakers, and Changemakers, O'Reilly Media, Inc.

Hassenzahl, M. (2003), "The Thing and I: Understanding the Relationship Between User and Product”, In: Blythe, M.A., Overbeeke, K., Monk, A.F. and Wright, P.C. (Eds.), Funology, Human-Computer Interaction Series, Springer Netherlands, pp. 31-42. https://doi.org/10.1007/1-4020-2967-5_4

Herst, D. (2012), "Participatory design”, In: van Abel, B., Klaassen, R., Evers, L. and Troxler, P. (Eds.), Open design now, BIS Publishers, Amsterdam.

Hohmann, L. (2006), Innovation Games: Creating Breakthrough Products Through Collaborative Play, Pearson Education.

Hyysalo, S., Kohtala, C., Helminen, P., Mäkinen, S., Miettinen, V. and Muurinen, L. (2014), "Collaborative futuring with and by makers", CoDesign, Vol. 10 No. 3-4, pp. 209-228. https://doi.org/10.1080/15710882.2014.983937

ISO (2010), 9241-210 - Ergonomie de l'interaction homme-système.

Keates, S. and Clarkson, P.J. (2003), "Countering design exclusion: bridging the gap between usability and accessibility", Universal Access in the Information Society, Vol. 2 No. 3, pp. 215-225. https://doi.org/10.1007/s10209-003-0059-5

Kremer, S. and Lindemann, U. (2015), “A Framework for Understanding, Communicating and Evaluatiing User Experience Potentials", Proceeding of the 20th International Conference on Engineering Design (ICED 15), Vol. 1, Design for Life, Milan, Italy. https://doi.org/10.1007/s10209-003-0059-5

Lallemand, C. (2015), Towards consolidated methods for the design and evaluation of user experience, $\mathrm{PhD}$ thesis, University of Luxembourg, Luxembourg.

Lallement, M. (2015), L’Âge du Faire: Hacking, travail, anarchie, Le Seuil.

Lobbé, J., Bazzaro, F., Charrier, M. and Sagot, J.-C. (2017), “Taking Into Account Life Situation During A Cocreativity Session: An Exploratory Study", 21st International Conference of Engineering Design (ICED17), Vol. 8, Human Behaviour in Design, Vancouver, Canada.

Lucero, A. (2009), Co-designing interactive spaces for and with designers: supporting mood-board making, $\mathrm{PhD}$ thesis, Eindhoven, the Netherlands: Eindhoven University of Technology. https://doi.org/10.6100/IR641288

Magnusson, C., Caltenco, H.A., McGookin, D., Kytö, M., Hjaltadóttir, I. et al. (2017), "Tangible Interaction for Stroke Survivors: Design Recommendations", Proceedings of the Eleventh International Conference on Tangible, Embedded, and Embodied Interaction, ACM, New York, NY, USA, pp. 597-602. https://doi.org/10.1145/3024969.3025073 
Maguire, M. (2001), "Methods to support human-centred design", International Journal of Human Computer Studies, Vol. 55 No. 4, pp. 587-634. https://doi.org/10.1006/ijhc.2001.0503

Makery (2014), Mais qui sont les fabmanagers? Makery mène l'enquête. [online] Makery. Available at: http://www.makery.info/2014/11/18/mais-qui-sont-les-fabmanagers-makery-mene-lenquete/ (accessed 21.10. 2017).

Makery (2017), Enquête Makery: les nouveaux métiers des fablabs. [online] Makery. Available at: http://www.makery.info/2017/04/04/enquete-makery-les-nouveaux-metiers-des-fablabs/_ (accessed 21.10.2017).

Martin, B. and Hanington, B. (2012), 100 méthodes de design, Eyrolles.

Menichinelli, M., Bosqué, C., Troxler, P., Raspanti, C., Schaub, A. and Neves, H. (2015), FabLab - La révolution est en marche, Pyramyd.

Morel, L. and Le Roux, S. (2016), Fab Labs - L'usager Innovateur, Smart innovation, Vol. 3, Iste Editions.

Nelson, J., Buisine, S. and Aoussat, A. (2013), “Anticipating the use of future things: Towards a framework for prospective use analysis in innovation design projects", Applied Ergononomics, Vol. 44 No. 6, pp. 948-956. https://doi.org/10.1016/j.apergo.2013.01.002

Pahl, G. and Beitz, W. (1996), Engineering Design: A Systematic Approach, Springer, London.

Patton, J. (2014), User Story Mapping: Discover the Whole Story, Build the Right Product, O'Reilly Media, Inc.

Quarante, D. (1994), Eléments de design industriel, Polytechnica.

Roussel, B. and Fleck, S. (2015), “«Moi, voilà ce que je voudrais que tu me fabriques!» (Lucie, âge 9): Design participatif pour l'utilisabilité de marqueurs tangibles en contexte scolaire", 27ème conférence francophone sur l'Interaction Homme-Machine, Toulouse, France, pp. a2. https://doi.org/10.1145/2820619.2820621

Sagot, J.-C., Gouin, V. and Gomes, S. (2003), "Ergonomics in product design: safety factor", Safety Science Journal Special Issue: Safety in Design, Vol. 41 No. 2-3, pp. 137-154. https://doi.org/10.1016/S09257535(02)00038-3

Sanders, E.B.-N. and Stappers, P.J. (2008), "Co-creation and the new landscapes of design”, CoDesign, Vol. 4 No. 1, pp. 5-18. https://doi.org/10.1080/15710880701875068

Sanders, E.B.-N. and Stappers, P.J. (2014), "Probes, toolkits and prototypes: three approaches to making in codesigning”, CoDesign, Vol. 10 No. 1, pp. 5-14. https://doi.org/10.1080/15710882.2014.888183

Sanders, E.B.-N., Brandt, E. and Binder, T. (2010), "A Framework for Organizing the Tools and Techniques of Participatory Design”, Proceedings of the 11th Biennial Participatory Design Conference, PDC '10. ACM, New York, NY, USA, pp. 195-198. https://doi.org/10.1145/1900441.1900476

Sennett, R. (2009), "Nouveau capitalisme et expertise quotidienne", Cahiers Internationaix de Sociologie, No. 126, pp. 13-20. https://doi.org/10.3917/cis.126.0013

Stappers, P.J., Visser, F.S. and Kistemaker, S. (2012), “Creation \& Co: User Participation in Design”, In: van Abel, B., Klaassen, R., Evers, L. and Troxler, P. (Eds.), Open Design Now, BIS Publishers, Amsterdam.

Triclot, M. (2011), Philosophie des jeux video, Zones.

Truong, K.N., Hayes, G.R. and Abowd, G.D. (2006), "Storyboarding: An Empirical Determination of Best Practices and Effective Guidelines", Proceedings of the 6th Conference on Designing Interactive Systems, DIS '06, ACM, New York, NY, USA, pp. 12-21. https://doi.org/10.1145/1142405.1142410

Ulrich, K. and Eppinger, S. (1999), Product design and development, 2nd ed.

Valentin, A., Lancry, A., Llorca, J.-M. and Lemarchand, C. (2010), "La situation: une base pour la conception ergonomique, des postes de travail aux produits grand public", In: Valléry, G., Le Port, M.-C. and Zouinar, M. (Eds.), Ergonomie, conception de produits et services médiatisés, Presses Universitaires de France, p. 131.

Vinck, D., Jeantet, A. and Laureillard, P. (1996), "Objects and Other Intermediaries in the Sociotechnical Process of Product Design: an exploratory approach", In: Perrin, J. and Vinck, D. (Eds.), The role of design in the shaping of technology, Vol. 5, COST A4 Social Sciences, EC Directorate General Science R\&D, Bruxelles, pp. 297-320.

Visser, F.S., Stappers, P.J., van der Lugt, R. and Sanders, E.B.-N. (2005), “Contextmapping: experiences from practice", CoDesign, Vol. 1 No. 2, pp. 119-149. https://doi.org/10.1080/15710880500135987

von Hippel, E. (2005), "Democratizing innovation: The evolving phenomenon of user innovation”, Journal Für Betriebswirtschaft, Vol. 55 No. 1, pp. 63-78. https://doi.org/10.1007/s11301-004-0002-8

Justine Lobbé, PhD student

Pôle de recherche ERCOS, laboratoire ELLIADD (E.A. 4661) Université de Bourgogne Franche-Comté -UTBM, 90010 Belfort Cedex, France

19 rue Georges Clemenceau, 25200 Montbeliard, France

Email: justine.lobbe@utbm.fr 